DOI 10.22460/infinity.v7i1.p7-14

\title{
A COMPARISON BETWEEN STAD-TYPE AND TPS-TYPE COOPERATIVE LEARNING IN MIDDLE SCHOOL STUDENTS' GEOMETRY LEARNING
}

\author{
Asri Ode Samura \\ IAIN Ternate, Jl. Lumba-Lumba, Marikurubu, Ternate City, North Maluku, Indonesia \\ asri22samura@gmail.com
}

Received: March 21, 2017 ; Accepted: July 11, 2017

\begin{abstract}
This study aims to describe and compare the effectiveness of the application of STAD and TPS types in cooperative learning to the students. This study was a quasi-experiments research in which students were designed into a form of the experimental group (pre-test and post-test group designs), where the cooperative learning of STAD and TPS types will be applied in learning mathematics. The population in this study were junior high school students in Ternate, while samples were taken by 60 random students who had the same characteristics as the population. The result of the study shows that cooperative learning model of both STAD and TPS types are very effective to be applied on studying mathematics. However, between the STAD and TPS types of cooperative learning, the STAD types are more effective than TPS, seen from accomplishing standards of competence, mathematical communication skills, and mathematical thinking ability of Junior High School students.
\end{abstract}

Keywords: Logical Reasoning, STAD, TPS.

\begin{abstract}
Abstrak
Penelitian ini bertujuan untuk mendeskripsikan perbandingan keefektifan penerapan pembelajaran kooperatif tipe STAD dan tipe TPS pada siswa. Penelitian ini merupakan penelitian quasi-eksperimen yang didesain menggunakan bentuk kelompok eksperimen pretes-postes (pretest-postest group design) kepada siswa yang akan diterapkan pembelajaran kooperatif tipe STAD dan Tipe TPS pada pembelajaran matematika. Populasi dalam penelitian ini adalah siswa SMP di Ternate, sedangkan sampel diambil 60 orang siswa secara acak yang memiliki karakteristik yang sama dengan populasi. Hasil penelitian menunjukkan bahwa: (1) Model pembelajaran kooperatif learning tipe STAD dan tipe TPS sangat efektif jika diterapkan pada pembelajaran matematika; (2) Kedua model pembelajaran kooperatif learning kelas tipe STAD dan tipe kelas TPS dilihat keefektifannya, lebih efektif kelas tipe STAD dibandingkan dengan kelas tipe TPS dilihat dari ketercapaian Standar Kompetensi, kemampuan komunikasi matematis, dan kemampuan berpikir matematis siswa SMP.
\end{abstract}

Kata Kunci: Penalaran Logis, STAD, TPS.

How to Cite: Samura, A.O. (2018). A Comparison between STAD-Type and TPS-Type Cooperative Learning in Middle School Students' Geometry Learning. Infinity, 7 (1), 7-14 doi:10.22460/infinity.v7i1.p7-14 


\section{INTRODUCTION}

Advances in sciences and technology requires that one has the ability to master the available information and knowledge (Herman, 2007), which necessitates the ability to obtain, sort and manage information. This ability must be based on critical, systematic and logical thinking as it is material to the analysisand evaluation of arguments in order to take rational and accountable decisions. Therefore, educational programs that can promote critical, systematic and logical thinking skills are needed, one of which is Mathematics.

The development of the world of mathematical education nowadays contitutes the connection between mathematics' function as a didactic science and as educational psychology. In fact, the position of mathematics as a science is mutli-interpretative in nature. Mathematics is one of the subjects taught at schools, including elementary schools, middle schools, high schools and college or university. Since mathematics taught at schools is part of mathematics, different characteristics and interpretations of mathematical contents from various points of view play a significant role in the development of sciences and technology.

Mathematics is an exact science and it is organized in a systematic manner. As a science, mathematics has logical and critical aspects that have consistent order. The knowledge of mathematics is formed through the thought of the experience of certain objects or events. Mathematical objecs are intended to motivate every level of education to learn mathematics.

Regarding the existence of mathematics, Hidayat (2017) describes the reason why it is important to learn mathematics. According to him, mathematics emphasizes more the activities in the rational world (reasoning) instead of experiments. In other words, mathematical observation is formed due to human thoughts which are related to ideas, processes and reasoning.

Consistent and logical mathematical structure is essential for everyone to develop their critical thinking skill for fulfilling his or her needs in life. This consistency requires mathematics teachers' professionalism in order to be able to act appropriately in selecting learning strategies or in explaining mathematical contents for the learning process at schools (Hidayat, Wahyudin, \& Prabawanto, 2018).

Competency in Mathematics refers to expertise performance capability, which is built through mathematical knowledge, skills and attitude fostering. One's mathematical competency can be seen from his or her capability in meeting the specification of the job, or performance capability in handling the job in mathematical activities. Competency and measurement of learning outcomes are closely related to learning process, either for teachers' purpose in improving the quality of the learning or for students' purpose in improving the learning outcomes. To put it simply, they want to know the grade that they have achieved. To answer this question, teachers need to develop a measurement instrument that can measure the mastery of competency referred to in the learning objectives.

By communicating ideas when learning, students will be able to use and control mathematical concepts with higher confidence than they have presently. Students have to assume a different role in the mathematics class, and so do the teachers. Students must be involved and responsible for their own learning, whereas the teachers must help them do so. Teachers may perform their task by: (1). changing the way students interact with their works and with each 
other; (2). providing them with more challenging problems to be solved, and (3). asking them to express mathematical ideas in writing.

Los Angeles County Office of Education (Mahmudi, 2009) mentions several forms of mathematical communication, namely (a) reflecting and clarifying thoughts on mathematical ideas; (b) linking everyday language with mathematical language, which uses symbols; (c) using the skills of reading, listening, interpreting, and evaluating mathematics ideas, and (d) using mathematical ideas to make conjectures and to convey convincing arguments.

Mathematical communication covers written communication and spoken or verbal communication. Written communication can be in the form of words, figures, tables or other forms which depict the thinking process of the students. Communication can be in the form of problem solving or mathematical proving, which describe the ability of the students in organizing various concepts when solving problems. Meanwhile, spoken communication can be in the form of verbal expression and explanation of a mathematical idea. Spoken communication may take place through interaction between students, for example when learning in a group discussion setting (Rahmi, Nadia, Hasibah, \& Hidayat, 2017).

The learning pattern developed in Indonesia nowadays requires students' activeness in the learning and teaching process, and students' creativity in processing the materials provided by the teacher. This is intended to allow meaningful reasoning construction and critical thinking in analyzing and solving mathematical problems faced by students. According to Hidayat (2012), students who think critically are those who are able to identify, evaluate and construct arguments, and who are able to solve problems correctly. Students who think critically will be able to help his or herself and others solve the problems encountered.

Creating learning situation that is fun, filled with cooperative spirit, wise and creative can be done through cooperative learning. Hidayat (2012) states that cooperative learning allows for fun learning situation, in which students will have equal opportunity, competition is turned into friendship, cooperation and participation spirit is reinforced, and all students have the right to be wise and creative. Cooperative learning is developed into a number of types. Among those types, the types of cooperative learning to be studied in this research are Student Teams Achievement Division (STAD) and Think Pair Share (TPS).

\section{METHOD}

The method of this research is a quasi-experiment research. It is designed using experimental groups (pre- test and post-test) to the group of students who applied the cooperative learning, both STAD and TPS types.

The research data analysis was focused on describing comprehensively the mean, standard deviation, variants, minimum score and maximum score of the data before and after treatment, the Standard Achievement Improvment, mathematical communication skills and mathematical thinking skills after the STAD type and TPS type cooperative learning was implemented.

The quantitative research data were obtained from pre-test and post-test given to 60 students before and after treatment using STAD type and TPS type cooperative learning. The qualitative research data were obtained from observation and interview. Observation included: the activities of students to whom cooperative learning were implemented, the activities of 
students and teacher (the researcher) in the implementation of STAD type and TPS type cooperative learning in learning Cube and Rectangular Prism. The interview data were obtained from some students to whom the cooperative learning had been implemented in accordance with the problem characteristics shown by students in answering and completing the research instrument.

Furthermore, in order to test the difference of competency standard achievement data, matheatical communication skills and mathematical thinking skills between those from pretest and those from post-test, statistic test: $t, t^{\prime}$ and Mann-Whitney $U$ were used. To meet the testing requirements, data normality and variants homogenity tests were conducted to every data pair. The normality test used Shapiro-Wilk (SW) statistics and the homogenity test for every data pair used Levene test. The data were analyzed using software SPPS for windows version 20.

\section{RESULTS AND DISCUSSION}

The description of competency standard achievement data, either for the class employing STAD or the class employing TPS, can be seen in Table 1.

Table 1. Description of Competency Standard Achievement Data

\begin{tabular}{lcccc}
\hline \multirow{2}{*}{ Description } & \multicolumn{2}{c}{ STAD } & \multicolumn{2}{c}{ TPS } \\
\cline { 2 - 5 } & Beginning & End & Beginning & End \\
\hline Mean & 50.23 & 97.09 & 49.79 & 92.67 \\
Theoretical Score & 100 & 100 & 100 & 100 \\
Maximum Score & 68.54 & 98.79 & 62.72 & 99.29 \\
Minimum Score & 39.34 & 71.95 & 32.91 & 57.89 \\
Standard Deviation & 8.72 & 8.19 & 7.78 & 8.94 \\
\hline
\end{tabular}

The data above revealed that the mean score of students competency standard achievement, either in class that employs STAD technique or class that employes TPS technique, before the treatment has yet to achieve the mean score of 75 , while after the treatment, the mean score exceeds 75 .

The description of mathematical communication skills data, for STAD and TPS techniques, are presented in Table 2.

Table 2. Description of Mathematical Communication Skills Data

\begin{tabular}{lcccc}
\hline \multirow{2}{*}{ Description } & \multicolumn{2}{c}{ STAD } & \multicolumn{2}{c}{ TPS } \\
\cline { 2 - 5 } & Beginning & End & Beginning & End \\
\hline Mean Score & 50.23 & 97.09 & 49.79 & 92.67 \\
Theoretic Maximum Score & 69.54 & 67.98 & 65.45 & 99.75 \\
Theoritic Minimum Score & 7.89 & 79.68 & 24.72 & 62.63 \\
Standard deviation & 11.62 & 7.94 & 13.43 & 12.76 \\
Variants & 149.09 & 68.74 & 199.87 & 165.71 \\
\hline
\end{tabular}

Based on Table 2, the mean score of students' mathematical communication skills, either in the class emloying STAD technique or the class employing TPS technique, before the 
treatment has yet to achieve the mean score of 75 , while after the treatment, the mean score exceeds 75 .

The description of the data of students' mathematical thinking skills in the mathematical learning process for classes that employed STAD and TPS can be seen in Table 3.

Table 3. Description of Mathematical Thinking Skills Data

\begin{tabular}{lcccc}
\hline \multirow{2}{*}{ Description } & \multicolumn{2}{c}{ STAD } & \multicolumn{2}{c}{ TPS } \\
\cline { 2 - 5 } & Beginning & Ending & Beginning & Ending \\
\hline Mean Score & 39.45 & 87.54 & 41.10 & 85.42 \\
Theoretical Maximum Score & 60.12 & 95.52 & 70.94 & 97.15 \\
Theroritical Minimum Score & 19.84 & 65.58 & 18.62 & 62.63 \\
Standard deviation & 10.83 & 12.79 & 15.65 & 12.57 \\
Variants & 125.15 & 105.17 & 176.86 & 98.17 \\
\hline
\end{tabular}

Based on Table 3, the mean score of students' creative thinking before the treatment is under 75. After receiving treatment using STAD and TPS techniques, the mean score exceeds 75 .

Now we are discussing the data normality and homogenity. The results of normality and homogenty tests of students' competency standard achievement, mathematical communication skills and mathematical thinking skills data before and after the treatment using STAD and TPS techniques are presented in Table 4 and 5.

Table 4. Normality Test Data

\begin{tabular}{lcc}
\hline Class & $\begin{array}{c}\boldsymbol{d}_{\boldsymbol{i}}^{\mathbf{2}} \\
\text { Before the } \\
\text { Treatment }\end{array}$ & $\begin{array}{c}\boldsymbol{d}_{\boldsymbol{i}}^{\mathbf{2}} \\
\text { After the } \\
\text { Treatment }\end{array}$ \\
\hline STAD & $65.75 \%$ & $55.35 \%$ \\
TPS & $56.54 \%$ & $60.15 \%$ \\
\hline
\end{tabular}

Table 4 shows that about $50 \%$ of the data has value $d_{i}^{2}<X_{(3: 0.5)}^{2}$. This means that the data of competency standard achievement, mathematical communication skills and mathematical thinking skills before and after the treatment using STAD technique in the class had met the normality assumption.

Table 5. Homogenity Test Data

\begin{tabular}{lcc}
\hline & $\begin{array}{c}\text { Before } \\
\text { Treatment }\end{array}$ & $\begin{array}{c}\text { After } \\
\text { Treatment }\end{array}$ \\
\hline Box"s $M$ & 5.785 & 10.569 \\
$F$ & 1.132 & 1.765 \\
Sig & 0.812 & 0.187 \\
\hline
\end{tabular}

Table 5 shows that the $\mathrm{F}$ significancy value is above 0.05.In other words, the competency standard achievement, mathematical communication ability and mathematical thinking values before and after treatment have met the homogenity assumption. 
The results of the test of cooperative learning effectiveness (STAD and TPS techniques) in the competency standard achievement, mathematical communication ability and mathematical thinking aspects are presented in Table 6.

Table 6. One Sample t-Test Result Data

\begin{tabular}{lcccc}
\hline \multirow{2}{*}{\multicolumn{1}{c}{ Aspects }} & \multicolumn{2}{c}{ STAD } & \multicolumn{2}{c}{ TPS } \\
\cline { 2 - 5 } & $\boldsymbol{t}_{\text {count }}$ & Sig & $\boldsymbol{t}_{\text {count }}$ & Sig \\
\hline Standard Achievements & 10.532 & 0.000 & 10.357 & 0.000 \\
Mathematical Communication Skills & 8.923 & 0.000 & 3.352 & 0.000 \\
Mathematical Thinking Skills & 7.632 & 0.000 & 5.324 & 0.000 \\
Mathematical Thinking Skills Questionnaire & 4.513 & 0.000 & 3.132 & 0.000 \\
\hline
\end{tabular}

Table 6 shows that the $t$ significancy values of all aspects are lower than 0.05 . This means that $\mathrm{H}_{0}$ is rejected. In other words, the STAD type and TPS type cooperative learning is effective viewed from the competency standard achievement, mathematical communication skills and mathematical thinking skills aspects. The results shown above conform with the theoretical review about both types of cooperative learning viewed from the three aspects being measured.

This is due to the fact that in the STAD type cooperative learning, students were active in the discussion in order to solve the problem, in which positive interdependence were established between students who continuously tried to improve their achievement in order that their groups receive reward.

In STAD type cooperative learning, students were directly involved in the learning, starting from understanding the problem until finding out the concept contained in the problems being faced. The involvement did not stop when they found the concept. It continued in the class discussion activity, either the discussion on concept finding or discussion on the result of working on the example or excercise in front of the class. Students were allowed to give responses, questions or even answers related to what had been delivered by other groups or particular students in front of the class during the discussion. Such activity made students not only skillful in answering questions, but also skillful in providing rationale related to the answers they offered/had. In every meeting in which STAD type cooperative learning was employed, rewards were given to groups, where students took part in contributing points to their groups. The group that achieved the highest score would be rewarded. The teacher told the students that whoever contributed the highest score/point to his or her group would boost his or her group's performance and make the group the best group. Such motivation will motivate students to make their respective group achieve the highest scores.

Besides, in the TPS type cooperative learning, students were given opportunities to solve problem-natured questions. Students were given time to solve their own problems (Think), in which they could have a better understanding on the problems given. At least, in this stage, students would have transient understanding and answers for the problems given. Afterwards, students were given an opportunity to sit in pairs to discuss the problem given, unify opinions/thoughts and find the concept. After finding the answer, students presented the results of thier discussion in front of the class (share). In this stage, students' understanding 
could increase because they had the chance to ask about what they did not understand to their friends or the group that presented their answers and shared ideas in front of the class.

The results that show whether there is any difference in the ability of both classes before and after the treatment, and whether there is any difference in the effectiveness of both cooperative learning types (STAD type and TPS type) viewed from the competency standard achievement, mathematical communication ability and mathematical thinking are presented in Table 7.

Table 7. MANOVA Result Data Before and After Treatment

\begin{tabular}{lcc}
\hline & $\boldsymbol{F}$ & Sig. \\
\hline Class (Before Treatment) & 0.635 & 0.655 \\
Class (After Treatment) & 9.322 & 0.000 \\
\hline
\end{tabular}

Table 7 shows that the data before treatment has $\mathrm{F}$ significance value greater than 0.05 , while the data after the treatment has F significance value lower than 0.05 . Thismeans that there is no difference in the initial ability between STAD type and TPS type class before the treatment viewed from the competency standard achievement, mathematical communication skills and mathematical thinking skills aspects. After the treatment, there is a difference in the effectiveness between STAD type and TPS type cooperative learning viewed from the competency standard achievement, mathematical communication skills and mathematical thinking skills aspects.

After finding out that there is a difference in the effectiveness between both learning methods, t-Benferroni test was conducted to see whether STAD type cooperative learning is more effective than TPS type cooperative learning viewed from the competency standard achievement, mathematical communication skills and mathematical thinking skills aspects. The results of $\mathrm{t}$-Benferroni test are presented in Table 8 .

Table 8. t-Benferroni Test Results

\begin{tabular}{lcc}
\hline \multicolumn{1}{c}{ Aspects } & $\begin{array}{c}\boldsymbol{t} \text { - } \\
\text { Benferroni }\end{array}$ & $\boldsymbol{t}_{\left(\frac{\alpha}{\boldsymbol{p}} ; \boldsymbol{n 1}+\boldsymbol{n 2} \mathbf{2}\right)}$ \\
\hline Competency Standard Achievement & 3.75 & 2.27 \\
Mathematical Communication Skills & 3.10 & 2.27 \\
Mathematical Thinking Skills & 2.45 & 2.27 \\
\hline
\end{tabular}

Table 8 describes that $\mathrm{t}$-Benferroni $>\mathrm{t}_{\mathrm{tab}}$. In other words, it can be said that STAD type cooperative learning is more effective than TPS type cooperative learning, which is viewed from the competency standard achievement, mathematical communication skills and mathematical thinking skills aspects.

These results are also in line with the theoretical review which revealed that STAD type cooperative learning is more effective than TPS type cooperative learning viewed from the three aspects that had been measured. This is the case in the learning process that used STAD model. It was also found that the students are not only involved in finding concept and class discussion, but also motivated to improve their groups' scores in order that their group gain greater reward than other groups. 
If this research is compared to other relevant studies, the results of this research are in line with those of the other studies. This can be seen from the results of other relevant studies that suggest that STAD type cooperative learning is more effective than TPS type cooperative learning viewed from the competency standard achievement, mathematical communication skills and mathematical thinking skills.

The results of the study have been described above, supported by a theoretical review of relevant studies such as Hendriana, Hidayat \& Ristiana (2018), but as mentioned earlier, some limitations that hindered this research were still found. Considering these weaknesses, some suggestions were offerred: this research is only limited to eight meetings to make it easy for assessing the competency standard achievement, mathematical communication ability and mathematical thinking. Besides, it takes a considerable time to be able to find out how well the three aspects develop. The researcher selected only materials about cube and rectangular prism on flat sides in this research, which limits generalization in relation to the research results.

\section{CONCLUSION}

According to the discussion above, based on the competency standard achievement, mathematical communication skills and creative thinking ability skills in the STAD type and TPS type cooperative learning, STAD type cooperative learning is more effective and efficient than TPS type cooperative learning.

\section{REFERENCES}

Hendriana, H., Hidayat, W., \& Ristiana, M. G. (2018). Student teachers' mathematical questioning and courage in metaphorical thinking learning. In Journal of Physics: Conference Series (Vol. 948, No. 1, p. 012019). IOP Publishing.

Herman, T. (2007). Pembelajaran berbasis masalah untuk meningkatkan kemampuan penalaran matematis siswa SMP. Cakrawala Pendidikan, 1(1), 41-62..

Hidayat, W. (2012). Meningkatkan Kemampuan Berpikir Kritis dan Kreatif Matematik Siswa SMA Melalui Pembelajaran Kooperatif Think-Talk-Write (TTW). In Seminar Nasional Penelitian, Pendidikan dan Penerapan MIPA.

Hidayat, W. (2017). Adversity Quotient dan Penalaran Kreatif Matematis Siswa SMA dalam Pembelajaran Argument Driven Inquiry pada Materi Turunan Fungsi. KALAMATIKA Jurnal Pendidikan Matematika, 2(1), 15-28.

Hidayat, W., Wahyudin, \& Prabawanto, S. (2018). Improving students' creative mathematical reasoning ability students through adversity quotient and argument driven inquiry learning. In Journal of Physics: Conference Series (Vol. 948, No. 1, p. 012005). IOP Publishing.

Mahmudi, A. (2009). Komunikasi dalam pembelajaran matematika. Jurnal Mipmipa Unhalu, 8(1), 1-9.

Rahmi, S., Nadia, R., Hasibah, B., \& Hidayat, W. (2017). The Relation between Self-Efficacy toward Math with the Math Communication Competence. Infinity Journal, 6(2), 177182. 